\title{
ROLA I MIEJSCE SPALARNI ODPADÓW W SYSTEMIE GOSPODAROWANIA ODPADAMI KOMUNALNYMI NA TLE REALIZACJI ZRÓWNOWAŻONEGO ROZWOJU
}

\section{THE ROLE AND PLACE OF WASTE INCINERATION IN A MUNICIPAL WASTE MANAGEMENT SYSTEM AGAINST THE REALIZATION OF SUSTAINABLE DEVELOPMENT}

\footnotetext{
STRESZCZENIE

Konsumpcyjny tryb życia oraz brak odpowiedniej infrastruktury, spowodował iż składowanie odpadów, stało się jedną z najczęściej sto-

* Asystent w Kancelarii Adwokackiej, doktorant w Katedrze Prawa Administracyjnego, Zakład Ochrony Środowiska i Nauki Administracji Publicznej, Wydział Prawa Uniwersytet w Białymstoku. 
sowanych metod gospodarowania odpadami komunalnymi. Termiczna utylizacja odpadów, powstałych w gospodarstwach domowych, stanowi jedną z możliwości, pozwalających na sprostanie wymogów unijnych, związanych z ograniczeniem odpadów na składowiskach. Powinno ono być stosowane, dopiero w sytuacji gdy nie możliwe jest ograniczenie strumienia śmieci ani poddania ich odzyskowi, recyklingowi. Biorąc pod uwagę możliwość wytworzenia energii z odpadów, oraz warunki techniczne spalarni śmieci, można pokusić się o stwierdzenie, iż ich termiczny odzysk realizowany jest w zgodzie ze zrównoważonym rozwojem.

\title{
Słowa kluczowe
}

Odpady, spalarnie odpadów, gospodarka odpadami komunalnymi, zrównoważony rozwój.

\begin{abstract}
Consumer lifestyles and the lack of adequate infrastructure, that caused the storage of waste has become one of the most widely used methods of waste management. Thermal utilization of waste generated in households, is one of the options for dealing with the EU requirements, relating to the reduction of waste in landfills. It should be used only when no flow is possible to limit or waste to submit their recovery, recycling. Given the opportunity to produce energy from waste and waste incineration technical conditions, one is tempted to say that their thermal recovery is realized in harmony with sustainable development.
\end{abstract}

\section{Keywords}

Waste, waste incinerators, municipal waste management, sustainable development.

\section{WSTĘP}

Rok 2012 jest rokiem szczególnym. Dwadzieścia pięć lat temu po raz pierwszy wskazano, iż jakość życia oraz poszanowanie dóbr naturalnych, które w zatrważającym tempie ulega4/2012 ją pomniejszeniu, winno stanowić fundamenty pod kreowanie 
nowej przyszłości. W tzw. Raporcie Brundtland podjęto próbę definicji zrównoważonego rozwoju rozumianego jako rozwój, który zaspokaja potrzeby obecne, nie zagrażając możliwościom zaspokojenia potrzeb przysztych pokoleń. Opiera się na dwóch podstawowych pojęciach:

- pojęciu „potrzeb”, w szczególności podstawowych potrzeb najbiedniejszych na świecie, którym należy nadać najwyższy priorytet;

- pojęciu ograniczeń, narzuconych zdolności środowiska do zaspokojenia potrzeb obecnych i przysztych przez stan techniki i organizacji społecznej ${ }^{1}$.

Jak podnosi J. Ciechanowicz-McLean, zasada zrównoważonego rozwoju powinna mieć charakter elastyczny, pozwalający na jej dostosowanie do zmian zachodzących na świecie w zakresie gospodarki, społeczeństwa oraz środowiska naturalnego. Pogląd ten jest jak najbardziej trafny, gdyż legalna definicja zawarta chociażby w art. 3 pkt 50 ustawy z dnia 27 kwietnia 2001 prawo ochrony środowiska ${ }^{2}$, biorąc pod uwagę burzliwe tempo przemian społecznych, okazać się może zbyt anachroniczna i nie pasująca do wciąż zmieniających się trendów ${ }^{3}$. Należy zgodzić się również z M. Jabłońskim, iż wyżej wymieniona zasada ma charakter zasady ustrojowej zawartej w art. 5 Konstytucji $\mathrm{RP}^{4}$. Co implikuje skutek taki, że odnosi się ona do wszystkich wskazanych w omawianym przepisie funkcji państwa ${ }^{5}$.

Ludzka natura oraz dotychczasowe przepisy prawa a może przede wszystkim niski stan świadomości dotyczącej zagrożeń płynących z nieprawidłowej gospodarki odpadami oraz wzrost produkcji samych odpadów, sprawił iż główną formą gospoda-

1 Komisja Ochrony Środowiska Naturalnego, Zdrowia Publicznego i Bezpieczeństwa Żywności, przygotowania do Szczytu RIO plus 20, dokument podstawowy 21 marca 2012 r., s. 2.

2 T.j. Dz. U. 2008 r. Nr 25, poz. 150 ze zm., dalej cyt.: u.p.o.ś.

3 J. Ciechanowicz- McLean (red.), Leksykon ochrony środowiska, Warszawa 2011, s. 401.

4 Konstytucja Rzeczypospolitej Polskiej z dnia 2 kwietnia 1997 r., Dz. U. z 1997 r. Nr 78, poz. 483 ze zm.

5 M. Jabłoński, Prawne przesłanki zrównoważonego rozwoju, Prawo i Środowisko, nr 2 (62)/10, s. 58. 
rowania odpadami w Polsce, jest ich składowanie na składowiskach. Mając na uwadze wyzwania związane z obowiązkiem zmniejszenia ich ilości, wynikające przede wszystkim z unijnych dyrektyw do których należy zaliczyć: dyrektywę Parlamentu Europejskiego i Rady 2008/98/WE z 19 listopada 2008 r. w sprawie odpadów oraz uchylająca niektóre dyrektywy ${ }^{6}$; dyrektywę Rady 1999/31/WE z 26 kwietnia 1999 r. w sprawie składowania odpadów ${ }^{7}$; dyrektywę Parlamentu Europejskiego i Rady 94/62/WE z 20 grudnia1994 r. w sprawie opakowań i odpadów opakowaniowych $^{8}$ - warto rozważyć możliwość zastosowania alternatywnych metod gospodarowania odpadami komunalnymi, w tym ich termicznej obróbki. Należy zastanowić się czy możliwe jest wykorzystywanie spalarni odpadów w zgodzie i poszanowaniu zasady zrównoważonego rozwoju oraz jakie miejsce $\mathrm{w}$ hierarchii metod gospodarowania odpadami komunalnymi powinna zająć termiczna utylizacji odpadów.

\section{POJĘCIE ODPADÓW}

Zgodnie z art. 3 ust. 1 ustawy z dnia 27 kwietnia 2001 r. o odpadach ${ }^{9}$, odpady oznaczaja każda substancje lub przedmiot należacy do jednej z kategorii, określonych $w$ załączniku $n r 1$ do ustawy, których posiadacz pozbywa się, zamierza pozbyć się lub do ich pozbycia sie jest obowiazany. Ustawodawca dokonał kategoryzacji odpadów przypisując im oznaczone symbole: Q1 - pozostałości z produkcji lub konsumpcji, niewymienione w pozostałych kategoriach; Q2 - Produkty nieodpowiadające wymaganiom jakościowym; Q3 - produkty, których termin przydatności do właściwego użycia upłynął; Q4 - substancje lub przedmioty, które zostały rozlane, rozsypane, zgubione lub takie, które uległy innemu zdarzeniu losowemu, w tym zanie-

6 Dz. Urz. UE L 312 z 22.11.2008, s. 3, dalej cyt.: dyrektywa ramowa.

7 Dz. Urz. UE L 182 z 16.07.1999, s. 1, ze zm.

8 Dz. Urz. UE L 365 z 31.12.1994, s. 10, ze zm.

9 T.j. Dz. U. z 2010 r. Nr 185, poz. 1243 ze zm., dalej cyt.: u.o.o. 
czyszczone wskutek wypadku lub powstałe wskutek prowadzenia akcji ratowniczej; Q5 - substancje lub przedmioty zanieczyszczone lub zabrudzone w wyniku planowych działań (np. pozostałości z czyszczenia, materiały z opakowań - odpady opakowaniowe, pojemniki, itp.); Q6 - przedmioty lub ich części nienadające się do użytku (np. usunięte baterie, zużyte katalizatory itp.); Q7 - substancje, które nie spełniają już należycie swojej funkcji (np. zanieczyszczone kwasy, zanieczyszczone rozpuszczalniki, zużyte sole hartownicze itp.); Q8 - pozostałości z procesów przemysłowych (np. żużle, pozostałości podestylacyjne itp.); Q9 - pozostałości z procesów usuwania zanieczyszczeń (np. osady ściekowe, szlamy z płuczek, pyły z filtrów, zużyte filtry itp.); Q10 - pozostałości z obróbki skrawaniem lub wykańczania (np. wióry, zgary itp.); Q11 - pozostałości z wydobywania lub przetwarzania surowców (np. pozostałości górnicze itp.); Q12 - podrobione lub zafałszowane substancje lub przedmioty (np. oleje zanieczyszczone PCB itp.); Q13 - wszelkie substancje lub przedmioty, których użycie zostało prawnie zakazane (np. PCB itp.); Q14 - substancje lub przedmioty, dla których posiadacz nie znajduje już dalszego zastosowania (np. odpady z rolnictwa, gospodarstw domowych, odpady biurowe, z placówek handlowych, sklepów itp.); Q15 - zanieczyszczone substancje powstające podczas rekultywacji gleby i ziemi; Q16 wszelkie substancje lub przedmioty, które nie zostały uwzględnione w powyższych kategoriach (np. z działalności usługowej, remontowej).

Biorąc pod uwagę ostatnią z przedstawionych kategorii, można dojść do wniosku, iż tak naprawdę pod pojęciem odpadu może znajdować się każda substancja. Tym samym, celem zbadania czy dany przedmiot można traktować jako odpad jest stwierdzenie czy jego posiadacz pozbywa się go, zamierza się pozbyć lub do jego pozbycia jest zobowiązany. Potwierdza to wyrok WSA w Warszawie z dnia 12 stycznia 2010 r. ${ }^{10}$, w którym sąd ten stwierdził, iż: możliwość zakwalifikowania substancji do jednej z kategorii wskazanych w zatączniku nr I do ustawy o odpa-

10 Wyrok WSA w Warszawie, z dnia 12 stycznia 2010r., sygn. akt IV SA/Wa 885/09. 
dach czy też jej uwzględnienia $w$ ramach normatywnej klasyfikacji odpadów nie przesadza o potrzebie jej uznania za odpad. Niezbędnym warunkiem jest bowiem aby wytwórca substancji wyzbywat sie jej lub zamierzat się wyzbyć (o ile wyzbycie się nie jest prawnie wymagane). Można zatem zauważyć, iż pojęcie odpadu jest ściśle związane z subiektywnym nastawieniem jego posiadacza do danej substancji. Należy również zgodzić się z K. Karpus, iż tłumaczenie definicji odpadów zawartej w polskiej ustawie nie jest spójne z najnowszą dyrektywą ramową, w myśl której odpadem jest każda substancja lub przedmiot, których posiadacz pozbywa się, zamierza się pozbyć, lub do których pozbycia zostat zobowiązany. Ustawodawca w dalszym ciągu stosuje terminologię odwołującą się do załącznika nr 1 (tak jak miało to miejsce w pierwotnej wersji dyrektywy ramowej) ${ }^{11}$. Wojewódzki Sąd Administracyjny w Lublinie w sentencji orzeczenia z dnia 21 maja 2008 r. ${ }^{12}$ wskazał, że konstrukcja definicji „odpadu” nie odwotuje się do cech substancji ani nie wskazuje na konkretne przedmioty które tworza odpad, lecz odwotuje się do wzorca wskazanego $w$ zataczniku do ustawy oraz do faktycznego, zamierzonego lub nakazanego postępowania. W związku z tym załacznik wymieniajacy kategorie odpadów nie musi wprost wskazywać, że dana substancja lub przedmiot jest odpadem, wystarczajace jest, że możliwe jest przyporządkowanie danej substancji do jednej z wymienionych $w$ załaczniku kategorii odpadów. Mając powyższe na uwadze, trzeba stwierdzić, iż istotnym elementem definicji odpadu jest zachowanie się podmiotu będącego jego posiadaczem. Prawodawca jednak nie precyzuje pojęcia „pozbywania się”. Zatem należy zgodzić się z W. Radeckim, iż nic nie stoi na przeszkodzie, by rozpatrywać je przez pryzmat naturalnego języka potocznego. Tym samym „pozbyciem się” będzie każde działanie, zarówno to zgodne z prawem (np. przekazanie odpadów do właściwego punktu zdawczego) lub sprzeczne z prawem, pod-

11 K. Karpus, Gospodarowanie odpadami w świetle orzecznictwa TS UE na gruncie dyrektyw ramowych $w$ sprawie odpadów, Włocławek 2011, s. 14.

12 Wyrok WSA w Lublinie z dnia 21 maja 2008 r., sygn. akt II SA/Lu 4/2012 17/08, LEX nr 489201. 
legające sankcjom karnym i administracyjnym (np. porzucenie zepsutej lodówki w lesie).

Jak wskazuje przywołany autor, tak naprawdę problem związany z niedoprecyzowaniem definicji odpadu, jest w wielu przypadkach wyolbrzymiany. Od dnia wejścia ustawy o odpadach do roku 2008 w sądach administracyjnych nie odnotowano ani jednego postępowania spornego, które chociażby w sposób pośredni, odnosiłoby się do definicji odpadu ${ }^{13}$. Odmiennie sytuacja wygląda w na gruncie orzecznictwa unijnego, gdzie takich sporów było wiele. Przykładem może być orzeczenie w sprawie C-422/92 ${ }^{14}$, gdzie stwierdzono, iż pojęcie odpadu $w \dot{z}$ adnym przypadku nie może nie obejmować substancji lub przedmiotów możliwych do powtórnego u̇̇ycia lub recyklingu, czy też orzeczenie w sprawie C-195/0515, gdzie Trybunał Sprawiedliwości UE stwierdził, że jeżeli poza zwykła możliwościa ponownego wykorzystania danej substancji jej posiadacz może odnieść korzyść ekonomiczna, prawdopodobieństwo do jego ponownego wykorzystania jest wysokie. W takich okolicznościach dana substancja nie może być nadal traktowana jako ciężar, który posiadacz zamierza usunać, ale winna być traktowana jako rzeczywisty produkt.

Reasumując, można stwierdzić, że aby zakwalifikować dany przedmiot, substancję jako odpad, należy dokonać każdorazowo analizy konkretnego stanu faktycznego w celu ustalenia czy posiadacz pozbywa się, ma zamiar się pozbyć lub do pozbycia się przedmiotu jest zobowiązany. Istotnym więc elementem tej definicji jest subiektywna wola posiadacza danej substancji. Ponadto trzeba podkreślić, iż przedmiot, substancja która może zostać ponownie wykorzystana do użytku, nie powinna być kategoryzowana jako odpad.

Należy również zauważyć, iż ustawodawca wprowadził definicję odpadów komunalnych w art. 3 pkt 4 u.o.o.: odpady

13 W. Radecki, Ustawa o odpadach, komentarz, Warszawa 2008, s. 80.

14 Wyrok TS UE z dnia 10 maja 1995 r. w sprawie C-422/92 Komisja Wspólnot Europejskich przeciwko Republice Federalnej Niemiec, Zb. Orz. TE [1995] I-01097.

15 Wyrok TS UE z dnia 18 grudnia 2007 r. w sprawie C-195/05 Komisja Wspólnot Europejskich przeciwko Republice Wtoskiej, Zb. Orz. TE [2007] I-11699. 
powstajace $w$ gospodarstwach domowych, z wyłaczeniem pojazdów wycofanych z eksploatacji, a takíe odpady niezawierajace odpadów niebezpiecznych pochodzace od innych wytwórców odpadów, które ze względu na swój charakter lub skład sa podobne do odpadów powstających $w$ gospodarstwach domowych. Przedmiotowa definicja oparta jest na dwóch kryteriach - miejsca pochodzenia odpadów - gospodarstwo domowe, oraz podobieństwa - w sytuacji, gdy odpady powstają poza gospodarstwem domowym, ale ze względu na swoje właściwości mają charakter tych odpadów ${ }^{16}$. Trzeba także zasygnalizować, iż odpady powstające w gospodarstwach domowych de facto mogą stanowić odpady, którym przypisuje się właściwości niebezpieczne.

\section{HIERARCHIA METOD GOSPODAROWANIA ODPADAMI KOMUNALNYMI}

Wzmożona konsumpcja oraz wysokoemisyjny tryb produkcji różnego rodzaju dóbr, doprowadził do sytuacji, w której człowiek zaczął dostrzegać konieczność stworzenia optymalnego, zintegrowanego systemu zarządzania odpadami. Priorytetowym założeniem wspomnianego sytemu miałoby być ograniczenie strumienia odpadów oraz poddanie tych już istniejących odpowiedniej obróbce. Jak wskazuje T. Pająk, cechą charakterystyczną tak pojmowanego modelu jest:

- zastosowanie kilku zintegrowanych, proekologicznych metod unieszkodliwiania odpadów;

- umożliwienie kompleksowej utylizacji szeroko rozumianych odpadów komunalnych ${ }^{17}$.

System gospodarki odpadami komunalnymi, dla swojego prawidłowego funkcjonowania, powinien być dostosowany do

16 A. Goździńska, System gospodarki odpadami komunalnymi, Samorząd Terytorialny 3/2009, s. 50.

17 T. Pająk, Termiczne unieszkodliwienie odpadów, $w$ systemie gospodarki tem gospodarki odpadami, Poznań-Piła, Polska, 27-30 maja 2001 r. 
każdej gminy indywidualnie. O zastosowaniu konkretnych metod gospodarowania odpadami decydować powinno poza uwarunkowaniami i wymogami prawnymi również położenie gminy, jej wielkość, ilość mieszkańców oraz wytwarzanych przez nich odpadów. Podstawowymi metodami utylizacji powstałych odpadów komunalnych są przede wszystkim:

- wymagająca udziału społeczeństwa, selektywna, wielopoziomowa zbiórka frakcji użytecznych;

- recykling organiczny;

- odseparowanie ze strumienia odpadów, ich odmian niebezpiecznych, celem unieszkodliwienia lub ponownego użycia;

- termiczna utylizacja;

- składowanie odpadów na kontrolowanych składowiskach $^{18}$.

Koszty alternatywnych metod gospodarowania odpadami są kilkakrotnie wyższe niż ich składowanie. Jednakże należy zauważyć, iż stoją one wyżej w hierarchii i są dalece pożądane na gruncie prawa ochrony środowiska. W ślad za T. Pająkiem, należy postawić zatem pytanie, jaką rolę i miejsce $\mathrm{w}$ systemie gospodarki odpadami komunalnymi, powinna zająć termiczna utylizacja odpadów. Czy biorąc pod uwagę obowiązujący stan prawny w szczególności dyrektywę ramową oraz u.o.o. możliwe by było zastosowanie metody termicznej jako jedynego sposobu gospodarki odpadami komunalnymi oraz czy w każdym takim systemie termiczna obróbka odpadów jest elementem obligatoryjnym? Wydaje się, iż na tak postawione pytanie odpowiedź powinna być przecząca. Metoda termicznego przekształcania odpadów w spalarniach, winna być stosowana dopiero w sytuacji, gdy nie możliwe jest zastosowanie pozostałych. Poza tym należy podkreślić, iż w związku z wymogami dyrektywy ramowej oraz opakowaniowej możliwości zastosowania termicznej obróbki odpadów są znacznie ograniczone.

Celem podsumowania trzeba zasygnalizować, iż w pierwszej kolejności należy zapobiegać powstawaniu odpadów. Jeżeli jest to niemożliwe, dokonać odzysku lub ich unieszkodliwienia

18 Ibidem. 
w taki sposób aby w jak najmniejszym stopniu miały one negatywny wpływ na środowisko naturalne. Ostatecznością powinno być, składowanie odpadów na składowisku.

\section{SPALARNIE ODPADÓW}

Ustawodawca definiuje pojęcie spalarni odpadów w art. 3 ust. 3 pkt 17 u.o.o., jako zakład lub jego część przeznaczone do termicznego przekształcania odpadów z odzyskiem lub bez odzysku wytwarzanej energii cieplnej, obejmujace instalacje i urzadzenia stużace do prowadzenia procesu termicznego przekształcania odpadów wraz z oczyszczaniem gazów odlotowych $i$ wprowadzaniem ich do atmosfery, kontrola, sterowaniem i monitorowaniem procesów oraz instalacjami związanymi z przyjmowaniem, wstępnym przetwarzaniem i magazynowaniem odpadów dostarczonych do termicznego przeksztatcania oraz instalacjami zwiazanymi z magazynowaniem i przetwarzaniem substancji otrzymanych $w$ wyniku spalania i oczyszczania gazów odlotowych. Przywołana definicja jest dość skomplikowana. Trzeba również zwrócić uwagę, iż spalarnią jest zakład rozumiany zgodnie $\mathrm{z}$ u.p.o.ś. W świetle znowelizowanych przepisów ustawy z dnia 13 września 1996r. o otrzymaniu czystości i porządku w gminach ${ }^{19}$ spalarnia odpadów może stanowić samodzielną instalację przetwarzania odpadów komunalnych. Jedynym wymogiem jest posiadanie mocy przerobowej pozwalającej na przetworzenie odpadów z obszaru zamieszkałego przez co najmniej 120 tys. mieszkańców oraz jej budowa i funkcjonowanie zgodne $\mathrm{z}$ najlepszymi dostępnymi technologiami i technikami. Poza tym trzeba podkreślić, iż taka instalacja powinna być uwzględniona $\mathrm{w}$ wojewódzkim planie gospodarki odpadami. Tylko wtedy, gminy będą mogły kierować tam swoje odpady. Warto również przypomnieć, iż budowa spalarni odpadów (zgodnie z prawem budowlanym) wyma- 
ga uzyskania pozwolenia na budowę. Zanim jednak inwestor wystąpi o uzyskanie pozwolenia do właściwego organu, niezbędnym będzie wydanie decyzji środowiskowej (obowiązek wynika z art. 46 rozporządzenia Rady Ministrów z dnia 9 listopada 2010 r. w sprawie przedsięwzięć mogących znacząco oddziaływać na środowisko ${ }^{20}$ ), która może zostać poprzedzona oceną oddziaływania na środowisko ${ }^{21}$.

Obecnie na terenie naszego kraju funkcjonuje tylko jedna spalarnia odpadów komunalnych w Warszawie. Trzeba podkreślić, iż budowa instalacji zajmujących się termicznym unieszkodliwianiem odpadów komunalnych jest jedyną możliwością, pozwalającą na spełnienie do roku 2015 unijnych wymogów związanych ze zmniejszeniem ilości odpadów na składowiskach. Jedenaście największych miast planuje realizację takich przedsięwzięć 22 . W Białymstoku w ramach projektu „Zintegrowany system gospodarowania odpadami dla aglomeracji białostockiej" do 2015 r. ma powstać spalarnia o przepustowości 120 tys. ton rocznie. Została ona uwzględniona w Planie Gospodarki Odpadami dla Województwa Podlaskiego na lata 2012-2017 i jak podnosi prezes Budimexu (firmy która wygrała przetarg na realizację przedsięwzięcia) wbrew pozorom, spalanie śmieci $w$ nowoczesny sposób jest dużo mniej szkodliwe dla środowiska, niz jakakolwiek inna utylizacja tych śmieci. Poza eliminacją odpadów z ekologicznego obiegu, spalarnia będzie również produkowała energię elektryczną i cieplną. Pozwoli to na odciążenie składowiska w Hryniewiczach i redukcję składowanych odpadów do $12 \%{ }^{23}$.

20 Dz. U. nr 213, poz. 1397.

21 M. Krzeszewska, Prawne aspekty budowy spalarni odpadów komunalnych, Inwestycje sektora publicznego 12/2011, s. 39.

22 K. Forowicz, Zielone światto dla spalarni, „Odpady i Środowisko” nr 6 (66) $/ 10$, s. 76.

23 http://www.wspolczesna.pl/apps/pbcs.dll/article?AID =/20120831/ REG00/120839921, stan na dzień 31 sierpnia 2012r. 


\section{5. „ZRÓWNOWAŻONE SPALANIE”?}

Mając na uwadze powyższe rozważania, należałoby się zastanowić, czy możliwe jest funkcjonowanie spalani odpadów w systemie gospodarki odpadami komunalnymi zgodnie z zasadą zrównoważonego rozwoju i zasadami „zielonej gospodarki”? W obecnym stanie techniki, spalarnie emitują 800 razy mniej pyłów lotnych i 1100 związków siarki, niż ciepłownie używające jako surowca energetycznego - węgla. Podnosi się, iż technologia termicznej obróbki odpadów jest jak najbardziej bezpieczna i nie zagraża środowisku. Jest ona wykorzystywana z powodzeniem w krajach skandynawskich. Jako przykład można wskazać spalarnię w Högdalen w Sztokholmie. Paliwem wykorzystywanym w tym zakładzie są odpady komunalne i przemysłowe, które dostarczają prąd 80 tys. mieszkańcom oraz ogrzewają około 200 tys. gosp. domowych. Wyżej wymieniona elektrociepłownia stanowi modelowy przykład współpracy PPP, na którym powinna opierać się gospodarka odpadami. Szwecji udało osiągnąć się niezależność energetyczną przede wszystkim dzięki temu, iż postawiła na pozyskiwanie energii cieplnej i elektrycznej z odpadów ${ }^{24}$.

Można zauważyć, iż zastosowanie metody termicznej w gospodarce odpadami komunalnymi przyczynia się do zmniejszenia ilości odpadów oraz redukcji udziału surowców naturalnych w procesach zmierzających do wytworzenia energii. Daje to przyszłym pokoleniom, szansę na korzystanie z zasobów Ziemi. Trybunał Konstytucyjny w wyroku z dnia 6 czerwca 2006 r., (sygn. akt K 23/05) stwierdził, że: $w$ ramach zasad zrównoważonego rozwoju mieści się nie tylko ochrona przyrody, ale i troska o rozwój społeczny i cywilizacyjny, związany z koniecznościa budowania stosownej infrastruktury ${ }^{25}$.

Można zatem pokusić się o stwierdzenie, iż de facto budowa i prawidłowe funkcjonowanie spalarni odpadów, zważywszy przede wszystkim na możliwości pozyskiwania energii z takich

24 J. Zientek-Varga, Co zrobić ze śmieciami? Może podpowiedzą nam sąsie-

25 OTK ZU 2006, nr 6A, poz. 62. 
instalacji, może stanowić determinantę rozwoju społecznego, cywilizacyjnego oraz ekologicznego kraju. Przy czym, przez rozwój ekologiczny należy rozumieć działania, zmierzające do ochrony środowiska naturalnego, polepszenie i zapewnienie jego prawidłowego funkcjonowania w myśl zasad zrównoważonego rozwoju oraz podnoszenie świadomości ekologicznej mieszkańców danego terenu. Tym samym można stwierdzić, iż możliwe jest funkcjonowanie spalarni opadów w systemie gospodarki odpadami komunalnymi z poszanowaniem zasad zrównoważonego rozwoju. W ogromnej mierze zależy to od zastosowanych technologii, prawidłowej interpretacji przepisów prawa oraz ludzkiej świadomości i mentalności.

\section{WNIOSKI KOŃCOWE}

Idea zrównoważonego rozwoju opiera się na zachowaniu równowagi między czynnikami społecznymi, ekonomicznymi oraz środowiskowymi. Tylko współdziałanie między tymi obszarami pozwoli na zapewnienie trwałego rozwoju gospodarczego, ochrony życia i zdrowia ludzkiego oraz środowiska naturalnego. Wydaje się, iż człowiek w końcu dostrzegł, że każde jego działanie ma wpływ na otaczające go środowisko. Wysokoemisyjna produkcja oraz wzmożona konsumpcyjność sprawiła iż ludzie zaczęli „tonąć” w odpadach. Celem spełnienia wymogów wynikających z przepisów unijnych należy zacząć poszukiwać alternatywnych metod gospodarki odpadami komunalnymi. Jedną $\mathrm{z}$ nich może być ich termiczna utylizacja. Zgodnie z obecnym stanem wiedzy i poziomem rozwoju techniki, podnosi się, iż spalarnie są bezpieczne dla środowiska i mają mniej negatywny wpływ niż pozostałe metody. Jednakże, powinny one być stosowane dopiero w sytuacji gdy nie udało się zapobiec powstaniu odpadów ani poddać ich procesom odzysku i recyklingu. Niemożliwe również wydaje się zbudowanie systemu gospodarki odpadami komunalnymi przy uwzględnieniu jedynie metody termicznej utylizacji odpadów. Biorąc pod uwagę wymogi stawiane przez ideę zrównoważonego rozwoju, można pokusić 
się o stwierdzenie, że spalarnie odpadów komunalnych, dzięki zastosowaniu innowacyjnych technologii oraz możliwości wytwarzania energii „odpadowej”, mogą być czynnikiem determinującym rozwój społeczny i cywilizacyjny. Zmniejszenie ilości odpadów składowanych na składowiskach, powinno wpłynąć na polepszenie zdrowia ludzkiego oraz stan środowiska naturalnego. Dzięki wzrostowi udziału alternatywnych źródeł energii (w tym energii pozyskiwanej z odpadów), zmniejszy się poziom eksploatacji naturalnych zasobów Ziemi. Zrodzi to szansę przyszłych pokoleń, na partycypację w wykorzystywaniu, wciąż wyczerpujących się surowcach naturalnych.

\section{BIBLIOGRAFIA}

Ciechanowicz-McLean J. ( red.), Leksykon ochrony środowiska, Warszawa 2011.

Forowicz K., Zielone światto dla spalarni, „Odpady i Środowisko” nr 6 (66) $/ 10$.

Goździńska A., System gospodarki odpadami komunalnymi, „Samorząd terytorialny" 3/2009.

Jabłoński M., Prawne przesłanki zrównoważonego rozwoju, „Prawo i Środowisko" nr 2(62)/10.

Karpus K., Gospodarowanie odpadami w świetle orzecznictwa TS UE na gruncie dyrektyw ramowych $w$ sprawie odpadów, Włocławek 2011.

Krzeszewska M., Prawne aspekty budowy spalarni odpadów komunalnych, Inwestycje sektora publicznego 12/2011.

Pająk T., Termiczne unieszkodliwienie odpadów, w systemie gospodarki odpadami komunalnymi, IV międzynarodowe forum gospodarki odpadami, System gospodarki odpadami, Poznań-Piła, Polska, 27-30 maja 2001.

Radecki W., Ustawa o odpadach, komentarz, Warszawa 2008.

Zientek-Varga J., Co zrobić ze śmieciami? Może podpowiedzq nam sq̨siedzi, Przyroda Polska 7/2011.

Kontakt email:

d.ostrowiecki@wp.pl 